\title{
Capture sequence and relative abundance of bats during surveys
}

\author{
Carlos E. L. Esbérard
}

Laboratório de Diversidade de Morcegos, Instituto de Biologia, Universidade Federal Rural do Rio de Janeiro. Antiga Rodovia Rio-São Paulo, km 47, Caixa Postal 74507, 23890-000 Seropédica, Rio de Janeiro, Brasil. E-mail: cesberard@superig.com.br

\begin{abstract}
It is expected that rare species will be gradually added to biodiversity surveys over time and that complete inventories will include rare species. The objective in the present work is to test whether the capture sequence of species during a bat survey is related to species abundance. Species with capture rates lower than $0.01 \times 10^{-3}$ captures/hour-net were considered rare. At Ilha da Gipóia, rare species accounted for $22.22 \%$ of the total and, at Rio das Pedras Reserve, they represented $30.00 \%$. The existence of a negative relationship between the relative abundance and the first night of capture of each species for the Ilha da Gipóia and the high significance level for the accumulation curve at both localities suggest that the documentation of a large number of rare species depends on a sustained capture effort. The common species were captured at the beginning of the field work and the remaining species were typically added to the collection according to their approximate relative abundance. However, rare or seldomly captured species were added at random.
\end{abstract}

KEY WORDS. Abundance; Atlantic Forest; sampling effort; methods; Southeastern Brazil.

Communities of neotropical bats, like other groups of animals, are composed of few very common species and many rare or seldomly captured species, when sampled with traditional methods (e.g. Findley 1993, Gaston 1994, Kalko et al. 1996). Rare species are those that exhibit reduced population sizes in regional or continental scales, but that may be locally abundant (GASTON 1994).

Although large numbers of bat species can be documented in an inventory in the Neotropical region, low similarity among localities may result, even if they are geographically close (see EsbÉRARD 2003, SAMPAIO et al. 2003). Twenty or more species have been described in surveys in the Atlantic Forest of southeastern Brazil (e.g. EsbéraRd 2003, Esbérard et al. 2006, Dias \& Peracchi 2008, Esbérard \& Bergallo 2008). It has been difficult to analyze which inventories are well-sampled but a minimum of 1,000 captures has been recommended for the Phyllostomidae of the Atlantic Forest of southeastern Brazil (Bergallo et al. 2003). In order to compare inventories, diversity indexes - such as Shannon's index (MAGURRAN 1988) - richness estimators - such as Chao's estimator based on the occurrence of rare species (Chao 1984, Bunge \& Fitzpatrick 1993, Colwell \& Coddington 1994) - or species accumulation curves (e.g. Soberón \& Llorente 1993, Dennis \& Ruggiero 1996) have been commonly used. However, if inventories are not successful in sampling rare species, species richness per se or richness estimates will be underestimated. A weakness of the Shannon Diversity index is the reduction of the community diversity to a single unique value (see Magnusson 2002), which does not adequately address rare species (Magurran 1988). It is expected that species that are rare due to sampling methodogy will be gradually added to inventories over time, and that inventories will include rare species based on the proportion of the completeness of the survey (see Снао 1984). The objective of this study is to test whether the capture sequence of species during a bat survey exhibits a relationship with species abundance.

\section{MATERIAL AND METHODS}

The data were obtained from two inventories carried out in the southern coast of the state of Rio de Janeiro. Both localities are situated in lowlands $(<100 \mathrm{~m})$ and their vegetation are classified as Dense Submontane Rainforest (Ururahy et al. 1983). Sampling was conducted with up to 13 mist nets of size $9 \times 2.5 \mathrm{~m}$ with $36 \mathrm{~mm}$ mesh, that were opened at ground level along forest edges, on established trails, over water bodies and close to fruiting trees (Esbérard 2003, EsbéraRd \& BERGALLo 2008) and conducted throughout the night and in all moon phases. The two localities considered in this analysis were: (a) Rio das Pedras Reserve at km 55 of BR $101 \mathrm{road}\left(22^{\circ} 59^{\prime} 26.4^{\prime \prime S}\right.$ and $\left.44^{\circ} 06^{\prime} 03.2^{\prime \prime} \mathrm{W}\right)$, with 1,361 ha and comprising areas from the coast up to $1,150 \mathrm{~m}$ a.s.l., including abandoned banana plantations, second-growth areas and primary forests (see Esbérard \& Bergallo 2008) and (b) Ilha da Gipóia, located in the municipality of Angra dos Reis $\left(23^{\circ} 02^{\prime} 20.36^{\prime \prime} \mathrm{S}, 44^{\circ} 21^{\prime} 34.80^{\prime \prime} \mathrm{W}\right)$, which is one of the largest islands of the state $\left(13.5 \mathrm{~km}^{2}\right), 0.8 \mathrm{~km}$ far from the continent, and has approximately $80 \%$ of its area covered with late second-growth forest resulting from regeneration and reforestation, with an estimated age of 115-130 years. Part of the data from Rio das Pedras Reserve were recently published (EsBÉRARD \& BERGALLo 2008).

In Rio das Pedras Reserve, 42 nights of sampling were carried out: a preliminary night in September 1995, 31 nights between January 1997 and June 1998, comprising two to three nights per month, and eleven random nights until 2005, which 
summed up to an effort of 492 hours and 3,313 m of mist nets. At Ilha da Gipóia, surveys were done between July 2004 and February 2008 (total of 29 nights with 337 hours of effort and $2,642 \mathrm{~m}$ of mist nets). Typically, two to four netting sessions were carried out per year.

Captures at roosts were not considered and nets remained at the same place during all field work at Ilha da Gipóia and during most of the sampling (32 nights) in Rio das Pedras Reserve. Species accumulation curves were made using EcoSim 7.26 (Gotelli \& ENTSMINGer 2001).

Captured bats were identified, measured and released, except for one or two individuals of each species that were deposited as vouchers in the collection of the "Projeto Morcegos Urbanos" (Urban Bats Project), located at Universidade Federal Rural do Rio de Janeiro (IBAMA process 1.755/89). In addition, all specimens of Desmodus rotundus (E. Geoffroy, 1810) were sacrificed to minimize attacks on domestic animals.

Animals were marked with a tattoo pincher that allowed temporary identification (until 1997), or with plastic necklaces with colored cylinders (EsbérARd \& DAEMon 1999). Recaptures were not considered in estimates of capture rates.

Diversity and evenness were calculated for each locality with Shannon's index (MagurRan 1988). In order to estimate how complete each inventory was the percentage of the richness in relation to Chao's estimate was calculated (CHAO 1984). To calculate the estimated number of species at each locality we used EstimateS 7.5 (Colwell 2005).

For each inventory, the capture rate for each species was expressed as total captures divided by the capture effort - $(\Sigma$ nets $x \Sigma$ hours) (Medelín et al. 2000), and the night in which a species was captured for the first time was recorded. A simple linear regression (ZAR 1996) was estimated between the capture rate and the night of the first capture to test whether the sequence of species accumulation was random. Sampling bias due to mist netting, such as bats with highly sensitive sonar to detect nets (Voss \& Emmons 1996) or species that fly higher than the ground-level nets (Findley 1993) were included in the calculation of relative abundance. Species represented by less than $0.01 \times 10^{-3}$ captures/hour-net were considered as rare, since that was the lowest capture rate obtained in these sampling.

\section{RESULTS}

At Ilha da Gipóia, a total of 1,776 bats were captured comprising 27 species and six families (Tab. I). The capture rate was 0.014 bats/h-net with an average of 61.24 captures per sampling night. At Rio das Pedras Reserve, there was a total of 1,287 captures comprising 29 species of six families (Tab. I). The capture rate was 0.007 bats/h-net with an average of 30.64 bats per sampling night. The expected number of species according to Chao's estimator was $35.71 \pm 3.78$ species for Ilha da Gipóia and $40.0 \pm$ 7.67 species for Rio das Pedras Reserve. The actual number of species sampled represented $75.6 \%$ and $77.5 \%$ of the estimated
Table I. Species netted at llha da Gipóia (Gipóia) and Rio das Pedras Reserve (Rio das Pedras) and their respective capture rate (captures/h-nets $\times 103$ ). Species rare or seldom netted in each local received an asterisk.

\begin{tabular}{|c|c|c|}
\hline Species & Gipóia & Rio das Pedras \\
\hline Artibeus lituratus (Olfers, 1818) & 4.305 & 1.538 \\
\hline Carollia perspicillata (Linnaeus, 1758) & 1.409 & 1.465 \\
\hline Artibeus obscurus (Schinz, 1821) & 1.401 & 0.443 \\
\hline Artibeus fimbriatus Gray, 1838 & 1.275 & 0.529 \\
\hline Phyllostomus hastatus (Pallas, 1767) & 0.897 & \\
\hline Sturnira lilium (E. Geoffroy, 1810) & 0.874 & 0.056 \\
\hline Artibeus planirostris (Spix, 1823) & 0.606 & 0.580 \\
\hline Noctilio leporinus (Linnaeus, 1758) & 0.488 & $0.009^{*}$ \\
\hline Molossus molossus (Pallas, 1766) & 0.488 & $0.004^{*}$ \\
\hline Anoura geoffroyi Gray, 1838 & 0.425 & 0.039 \\
\hline $\begin{array}{l}\text { Platyrrhinus lineatus (E. Geoffroy, } \\
1810 \text { ) }\end{array}$ & 0.386 & 0.146 \\
\hline Desmodus rotundus (E Geoffroy, 1810) & 0.283 & 0.146 \\
\hline Myotis nigricans (Schinz, 1821) & 0.236 & 0.017 \\
\hline Platyrrhinus recifinus (Thomas, 1901) & 0.205 & 0.013 \\
\hline Glossophaga soricina (Pallas, 1766) & 0.197 & 0.073 \\
\hline Myotis riparius Handley, 1960 & 0.189 & 0.043 \\
\hline Vampyressa pusilla (Wagner, 1843) & 0.102 & 0.064 \\
\hline Anoura caudifer (E.Geoffroy, 1818) & 0.063 & 0.146 \\
\hline Saccopteryx leptura (Schreber, 1774) & 0.039 & $0.004^{*}$ \\
\hline $\begin{array}{l}\text { Lonchophylla bokermanni Sazima, } \\
\text { Vizotto \& Taddei, } 1978\end{array}$ & 0.031 & 0.017 \\
\hline Lonchorhina aurita Tomes, 1863 & & 0.056 \\
\hline Micronycteris megalotis (Gray, 1842) & 0.031 & 0.017 \\
\hline Chiroderma doriae Thomas, 1891 & $0.008^{*}$ & 0.017 \\
\hline Chrotopterus auritus (Peters, 1856) & & 0.013 \\
\hline Chiroderma villosum Peters, 1960 & $0.008^{*}$ & $0.004^{*}$ \\
\hline Peropteryx macrotis (Wagner, 1843) & $0.008^{*}$ & \\
\hline Thyroptera tricolor Spix, 1823 & $0.008^{*}$ & $0.004^{*}$ \\
\hline Pygoderma bilabiatum (Wagner, 1843) & $0.008^{*}$ & $0.004^{*}$ \\
\hline Lonchophylla mordax Thomas, 1903 & & $0.009^{*}$ \\
\hline $\begin{array}{l}\text { Macrophyllum macrophyllum (Schinz, } \\
\text { 1821) }\end{array}$ & $0.008^{*}$ & \\
\hline Mollossus rufus E. Geoffroy, 1805 & & $0.004^{*}$ \\
\hline Sturnira tildae (de la Torre, 1959) & & 0.030 \\
\hline
\end{tabular}

richness, respectively. Shannon's diversity index was $\mathrm{H}^{\prime}=2.42$ for Ilha da Gipóia and $\mathrm{H}^{\prime}=2.16$ for Rio das Pedras Reserve. The evenness score was 0.736 for Ilha da Gipóia and 0.620 for Rio das Pedras Reserve. The species accumulation curves did not stabilize at an asymptote for either locality (Fig. 1).

The dominant species in terms of relative abundance was Artibeus lituratus (Olfers, 1818), with $30.80 \%$ and $27.82 \%$ of all 

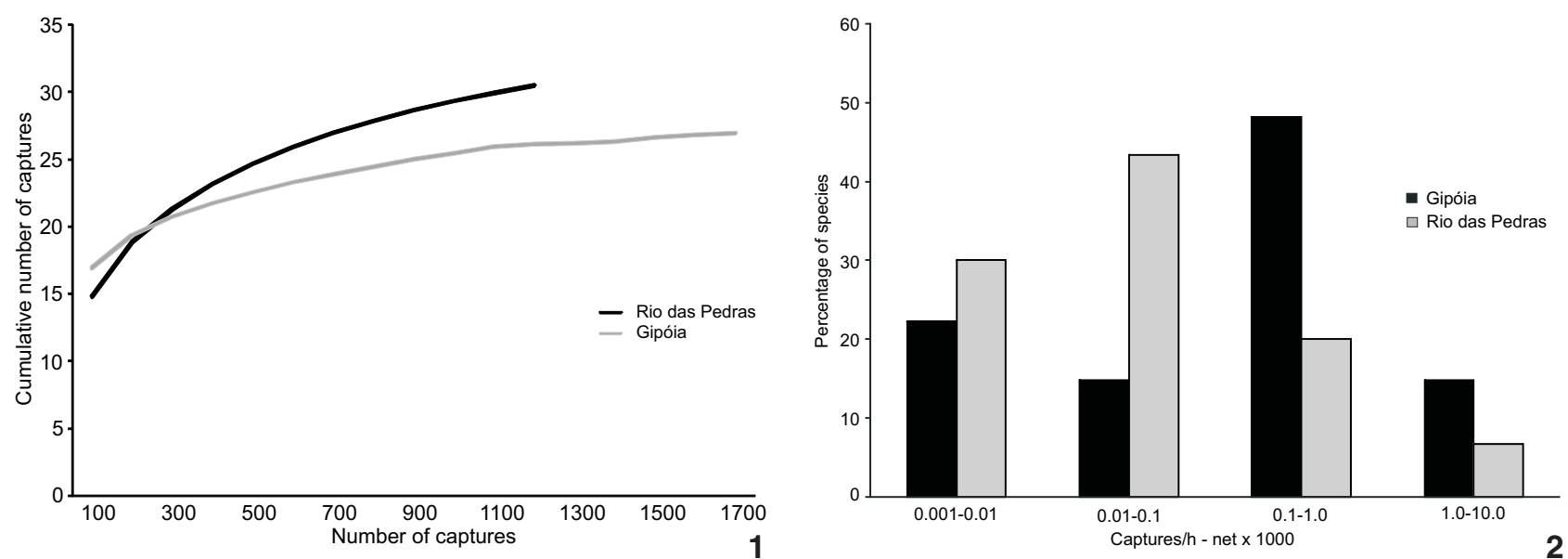

Figures 1-2. (1) Species accumulation curve and the total captures for Ilha da Gipóia and Rio das Pedras Reserve; (2) percentage of species according to capture rate for Rio das Pedras Reserve and Ilha da Gipóia.

captures at Ilha da Gipóia and Rio das Pedras Reserve, respectively. Carollia perspicillata (Linnaeus, 1758) was the second most frequent species at both localities, with 10.08 and $26.49 \%$ of all captures, respectively.

The time until the first capture of rare species at Ilha da Gipóia was on average $15.33 \pm 7.28$ nights (median $=14.5$ nights, minimum $=5$, maximum $=24, \mathrm{~N}=6$ ), and at Rio das Pedras Reserve was $18.25 \pm 13.34$ nights (median $=15$ nights, minimum $=3$, maximum $=37, \mathrm{~N}=8$ ). At Ilha da Gipóia, rare species represented $22.22 \%$ of all species and in Rio das Pedras Reserve $30.00 \%$ (Fig. 2). In both localities the highest percentage of species were obtained with intermediate values of capture efficiency; $43.33 \%$ of species with $0,01-0,10 \times 10^{-3}$ captures/ h-net in Rio das Pedras Reserve, and $48.15 \%$ of species with10$1.00 \times 10^{-3}$ captures/h-net in Ilha da Gipóia (Fig. 2).

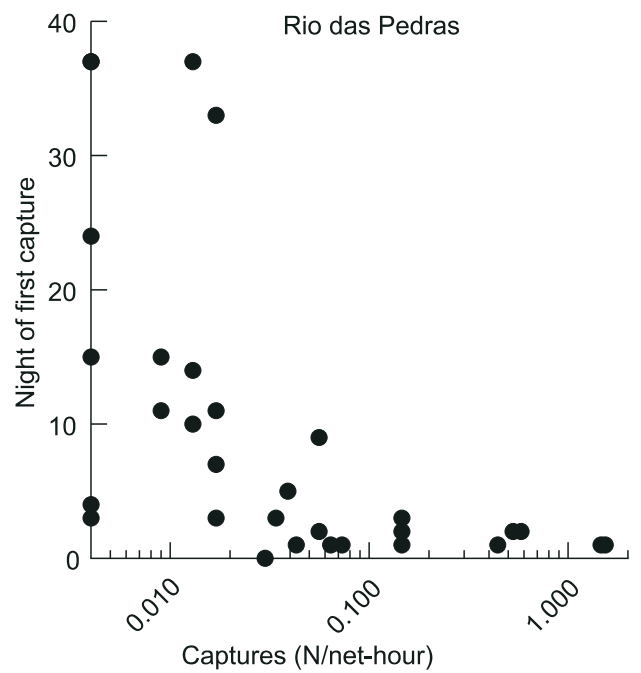

A significant and negative relationship was observed between the first night of capture of a species and its capture rate at Ilha da Gipóia $(\mathrm{y}=-3.505 \mathrm{x}+7.532, \mathrm{r}=0.409, \mathrm{~N}=27, \mathrm{~F}=5.213$, $\mathrm{p}=0.031$ ), and a non-significant relationship was observed in Rio das Pedras Reserve $(\mathrm{r}=0.333, \mathrm{~N}=30, \mathrm{~F}=3.481, \mathrm{p}=0.073$ ) (Fig. 3). A high significant and positive relationship was observed between the rare species accumulations and the total of sampling nights for both locals (for Ilha da Gipóia $y=0.253 x+0.582$, $\mathrm{r}=0.97, \mathrm{p}=0.000, \mathrm{n}=6$ and for Rio das Pedras Reserve $\mathrm{y}=$ $0.197 \mathrm{x}+1.590, \mathrm{r}=0.95, \mathrm{p}=0.001, \mathrm{n}=8$ ) (Fig. 4). A high significant relationship was also achieved between the number of rare species recorded and the total of captures $(\mathrm{y}=0.004 \mathrm{x}+0.1471$, $\mathrm{r}=0.98, \mathrm{~N}=6, \mathrm{~F}=103.271, \mathrm{p}=0.001$ for Ilha da Gipóia and $\mathrm{y}=$ $0.059 \mathrm{x}+0.8729, \mathrm{r}=0.99, \mathrm{~N}=6, \mathrm{~F}=141.252, \mathrm{p}<0.001$ for Rio das Pedras Reserve) (Fig. 4).

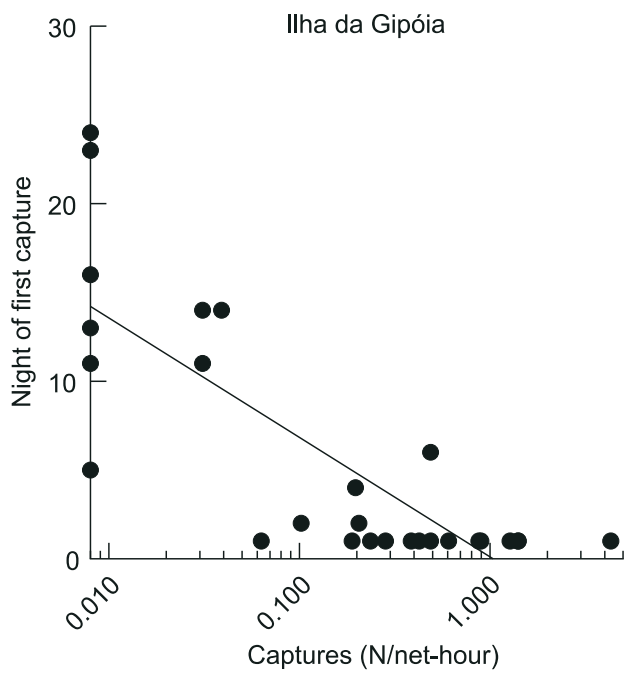

Figure 3. Relationship between first night of capture and number of captures for all species in Rio das Pedras Reserve and Ilha da Gipóia. 

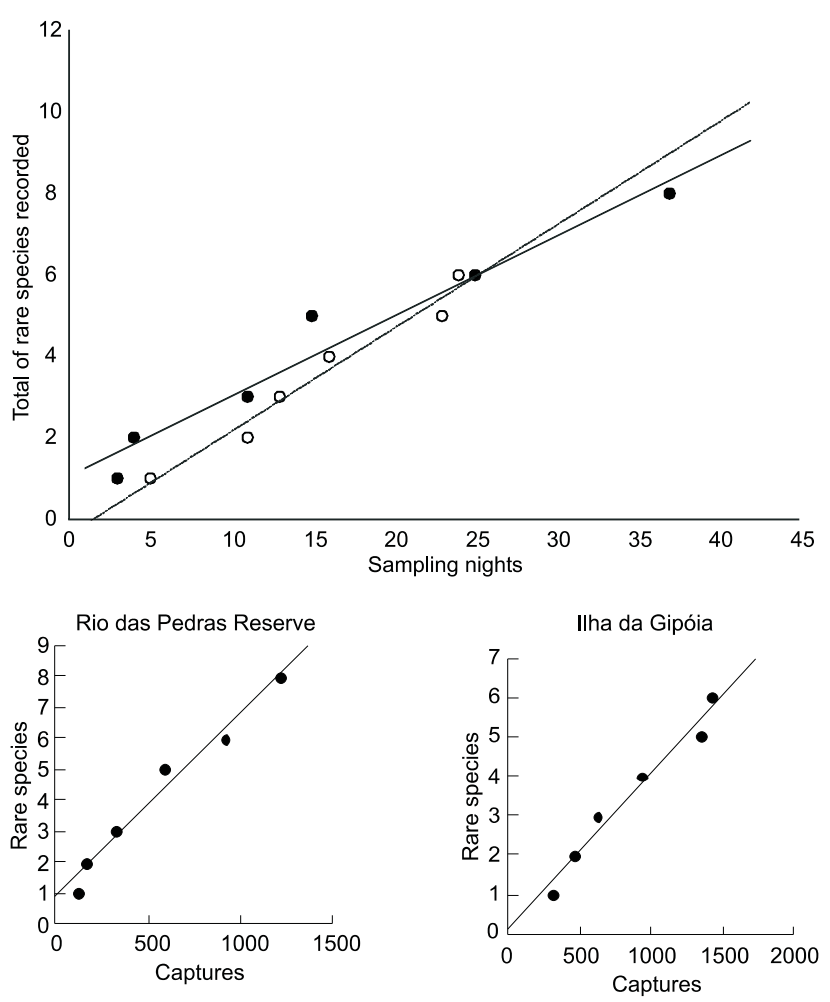

Figure 4. Accumulation curve of rare species for number of night samplings in Rio das Pedras Reserve (black dots and black line) and Ilha da Gipóia (white dots and dotted line) and for captures in Rio das Pedras Reserve and Ilha da Gipóia.

\section{DISCUSSION}

Both inventories analyzed in this study exhibited similar richness, corresponding to $38.02 \%$ and $43.66 \%$ of the total species recorded for Rio de Janeiro state (Esbérard \& Bergallo 2005). Both inventories also have similar dominant species in terms of relative abundance. However, the two inventories differ in terms of capture rate, which was twice as high at Ilha da Gipóia as at Rio das Pedras Reserve. Higher density could be expected in insular populations, due to the reduction of probable competitors and predators (e.g. MACARThur et al. 1972, Lomolino 1984). Furthermore, in Ilha da Gipóia a high number of fruiting trees was introduced in the last century and an artificial lake was built that could act to promote an increase in the populations of bat species.

The existence of a negative relationship between the relative abundance and the first night of capture of each species for Ilha da Gipóia, and the high significance level for the accumulation curve at both localities suggest that the documenting of rare species depends on a sustained capture effort. However, there was no similar significant relationship for the total captures and the first capture of the rare species at Rio das Pedras
Reserve indicating perhaps that continental populations may not have a limiting capacity in terms of relative abundance as do island populations. The common species are typically captured at the beginning of the field work, and the remaining species are added according to their approximate relative abundance. However, rare species may be added at any time during the survey, and a large number of rare species could be added only with large sampling effort. Very common species, such as members of the genus Artibeus, Carollia perspicillata (Linnaeus, 1758) and Sturnira lilium (E. Geoffroy, 1810) (EsbÉRARD \& BERGALLO 2008), were added during the first sampling nights. Common species such as Desmodus rotundus (E Geoffroy, 1810), Glossophaga soricina (Pallas, 1766) and Anoura caudifer (E.Geoffroy, 1818) (Esbérard \& Bergallo 2008) were also added near the beginning of the sampling period. Species represented by one or two specimens appear randomly during the survey period and were observed on average every 4.83 sampling nights at Ilha da Gipóia and 5.25 nights at Rio das Pedras Reserve.

To achieve the total number of species estimated by Chao's estimator, an additional 337 sampling hours would be necessary (total of 841 hours) at Ilha da Gipóia and 567 sampling hours (total of 1,071 hours) at Rio das Pedras Reserve. In terms of the average number of captures per night, for Ilha da Gipóia, 2,572 more captures would be necessary (total of 4,348 captures), and for Rio das Pedras Reserve 1,448 more captures would be necessary (total of 2,737 captures) to achieve the number of species estimated by Chao's estimator. Using these values in the equation obtained by regression of the amount of rare species and the total captures, both localities will achieve almost an equal number of rare species (17.54 to Ilha da Gipóia and 17.02 to Rio das Pedras Reserve). The total of 70-90 nights will be needed to obtain this amount of rare species. However, few surveys in Brazil have been of such duration and none of them kept nets in the same place for so long (Bergallo et al. 2003). Although based on estimations for similar areas, these data suggest that it is interesting to compare multiple sites to obtain minimum efforts for sampling and planning bat inventories.

According to the criterion used in this analysis, rare species are less numerous than species with intermediate capture values, although some authors described rare species as the major portion of each community (e.g. FindLey 1993, Gaston 1994). Bat communities studied in this region and nearby areas exhibit a percentage of species represented by one or two captures varying from $17.86 \%$ to $22.86 \%$ of all species (EsBÉRARD et al. 2006, Dias \& Peracchi 2008). KalKo et al. (1996) classified as rare 16 out of 66 species (24.24\%) found in Barro Colorado Island, Panama, during 85 years of sampling, and these species exhibited less than 10 captures from a total of over 48,000 captures. Apparently reduced capture efforts may result in a higher number of species with one or two captures. For example, between $25.9 \%$ and $42.1 \%$ of the species (average of $32.13 \%$ ) were represented by singletons and doubletons at six localities at Maciço da Tijuca, southeastern Brazil, sampled by 14.469 to 
24.830 h-net with successes that varied between 530 and 844 captures (EsbÉRARD 2003).

During another study in the same region reported herein, EsbéRARD \& BERGALlo (2008) used different sampling efforts, including the search for roosts, and obtained less than $75 \%$ of the total species for the southern coast of the state of Rio de Janeiro, even with a high number of sampling nights. Large sampling effort is needed to capture the less common species of bats using mist nets. In order to sample $90 \%$ of the Mormoopidae and Phyllostomidae fauna in a homogeneous area in the Amazonian region, Moreno \& HalfFTER (2000) estimated that five to 18 nights ( 15 to $54 \mathrm{~h}$ of sampling) would be necessary, using 20 nets per night. SAMPAIO et al. (2003) calculated that during 29.900 h-net with nets in the canopy and in the understory they sampled approximately 95\% of the bat fauna of Manaus, Amazonas, and concluded that 2,000 captures are necessary to sample at least $75 \%$ of the local bat fauna. Even using three different methods (canopy nets, understory nets and roost search), Simmons \& Voss (1998) estimated that they sampled approximately $77 \%$ of the species expected for Paracou, French Guiana. Even in temperate regions the mist net effort must be large, with more than 26 surveys needed to capture eight of the nine core species (WeLLER \& LeE 2007). Bergallo et al. (2003) suggested a minimum of 1,000 captures to satisfactorily sample bats in Rio de Janeiro State. To obtain 1,000 captures would require 18 nights at Ilha da Gipóia and 27 nights at Rio das Pedras Reserve but only four and six rare species would be recorded, respectively.

Sampling throughout the night increases the probability of capture of rare species (Simmons \& Voss 1998, EsbéraRd \& BERGALLO 2006). The permanence of nets in the same place results in a gradual decrease of capture success (Kunz \& KuRTA 1988, EsBÉRARD 2006), therefore it is worthwhile to switch sampling sites every night (Weller \& Lee 2007). Sampling carried out during the same phase of the moon cycle resulted in lower diversity, richness and number of captures (EsBérARD 2007). This suggests that other aspects of the sampling methodology traditionally used should be evaluated for a thorough understanding of sampling bias.

Bat species lists still represent the most accessible indicator of biodiversity in Brazil (Uieda \& Pedro 1996, Bergallo et al. 2003); however this information cannot be properly used if they are incomplete or undersampled. The proportion of rare species can be a valuable aspect for consideration if sampling was satisfactorily achieved.

\section{ACKNOWLEDGEMENTS}

Thanks to Club Med, maintainer of Rio das Pedras Reserve, and Fazenda da Gipóia/Sogim Empreendimentos, for support and sampling permission; A.F.P.D. Fernandes, A.G. Motta, E.C. Lourenço, D.S. França, J. Almeida, J.L. Luz, L.A.C. Gomes, L.M. Costa, M.C. Enrici, R.M. Silva and T. JordãoNogueira (Laboratório de Ecologia da UERJ and Laboratório de
Diversidade de Morcegos, UFRRJ) for the help in field work; and D. Dias and A.L. Peracchi (Laboratório de Mastozoologia, UFRRJ) for confirming the identification of some voucher specimens. Two anonymous referees improved the final manuscript. Specimen collection was carried out under a permanent sampling license of SISBIO/IBAMA (10356-1). This work was developed with the support of Universidade Gama Filho, Fundo de Conservação Ambiental/SMAC (Process 14/001.917/97), Instituto Biomas, Conservation International and FAPERJ (process E-26/170.449/07). The author thanks the Research Productivity Fellowship from CNPq (process 301061/2007-6).

\section{LITERATURE CITED}

Bergallo, H.G.; C.E.L. Esbérard; M.A.R. Mello; V. Lins; R. Mangolin; G.G. S. Melo \& M. Baptista. 2003. Bat Sampling in Atlantic Forest: How much should the minimum effort be? Biotropica 35 (2): 278-288.

Bunge, J. \& M. FitzPatrick. 1993. Estimating the number of species: a review. Journal of American Statistical Association 88: 364-373.

ChaO, A. 1984. Nonparametric estimation of the numbers of classes in a population. Scandinavian Journal of Statistics 11: $265-270$.

Colwell, R.K. 2005. EstimateS: Statistical estimates of species richness and share of species of samples. University of Connecticut, version 7.5, disposable in http://purl.oclc.org/ estimates.

Colwell, R.K. \& J.A. Coddington. 1994. Estimating terrestrial biodiversity through extrapolation. Philosophical Transactions of the Royal Society of London, Series B 345: 101118.

Dennis, J.G. \& M.A. Ruggiero. 1996. Biodiversity inventory: Building as inventory at scales from local to global, p. 149156. In: R.C. Szaro \& D.W. Johnston (Eds). Biodiversity in managed landscapes. New York, Oxford University Press, 808p.

Dias, D. \& A.L. Peracchi. 2008. Quirópteros da Reserva Biológica do Tinguá, estado do Rio de Janeiro, sudeste do Brasil (Mammalia: Chiroptera). Revista Brasileira de Zoologia 25 (2): 333-369.

Esbérard, C.E.L. 2003. Diversidade de morcegos em uma área de Mata Atlântica regenerada no sudeste do Brasil (Mammalia: Chiroptera). Revista Brasileira de Zoociências 5 (2): 189204.

EsbéraRd, C.E.L. 2006 Efeito da coleta de morcegos por noites seguidas no mesmo local. Revista Brasileira de Zoologia 23 (4): 1093-1096.

EsbéraRd, C.E.L. 2007. Influência do ciclo lunar na captura de morcegos phyllostomidae. Iheringia, Série Zoologia, 97 (1): 81-85.

Esbérard, C.E.L. \& H.G. Bergallo. 2005. Research on bats in the state of Rio de Janeiro, southeastern Brazil. Mastozoologia Neotropical 12 (2): 237-243. 
Esbérard, C.E.L. \& H.G. Bergallo. 2006. Coletar morcegos por seis ou doze horas a cada noite? Revista Brasileira de Zoologia 22 (4): 1095-1098.

Esbérard, C.E.L. \& H.G. Bergallo. 2008. Influência do esforço amostral na riqueza de espécies de morcegos no sudeste do Brasil. Revista Brasileira de Zoologia 25 (1): 67-73.

Esbérard, C.E.L. \& C. Daemon. 1999. Novo método para marcação de morcegos. Chiroptera Neotropical 5 (1-2): 116-117.

Esbérard, C.E.L.; T.J. Jordẽo-Nogueira; J.L. Luz; G. Melo; R. Mangolin; N. Jucá; D.S. Raíces; M.C. Enrici \& H.G. Bergallo. 2006. Morcegos da Ilha Grande, Angra dos Reis, RJ. Revista Brasileira de Zoociências 8 (2): 147-153.

FindLeY, J.S. 1993. Bats - A community perspective. London, Cambridge University Press, Cambridge Studies in Ecology, $167 \mathrm{p}$.

GaSTON, K.J. 1994. Rarity. London, Chapman \& Hall, Population and Community Biology Series 13, 205p.

Gotelli, N.J. \& G.L. EnTSMinger. 2001. EcoSim: null models software for ecology. London. Acquired Intelligence Inc. \& Kesey-Bear, Version 7.26.

Kalko, E.K.V.; C.O. Handley \& D. Handley. 1996. Organization, diversity and long-term dynamics of a neotropical bat community, p. 503-553. In: M.L. Cody \& J.A. SMallwood (Eds). Long-term studies of vertebrate communities. San Diego, Academic Press, 597p.

Kunz, T.H. \& A. KurTA. 1988. Capture methods and holding devices, p. 1-30. In: T.H. Kunz (Ed.). Ecology and behavioral methods for the study of bats. Washington, Smithsonian Institution Press, 533p.

Lomolino, M.V. 1984. Immigrant selection, predatory exclusion and the distribution of Microtus pennsylvanicus and Blarina brevicauda on islands. American Naturalist 123 (4): 468-483.

MacArthur, R.H.; J.M. Diamond \& J. Karr. 1972. Density compensation in island faunas. Ecology 53 (2): 330-342.

Magnusson, W.E. 2002. Diversity indices: Multivariate candies from Pandora's box. Bulletin of Ecological Society of Ame- rica 83 (1): 86-87.

Magurran, A.E. 1988. Ecological diversity and its measurement. London, Croom Helm, 179p.

Medellín, R.A.; M. Equinua \& M.A. Amin. 2000. Bat diversity and abundance as indicators of disturbance in neotropical rainforests. Conservation Biology 14: 1666-1675.

Moreno, C.E. \& G. Halffter. 2000. Assessing the completeness of bat biodiversity inventories using species accumulation curves. Journal of Applied Ecology 37: 149-158.

Sampaio, E.M.; E.K.V. Kalko; E. Bernard; B. Rodriguez-Herrera \& C.O. Handley JR. 2003. A biodiversity assessment of bats (Chiroptera) in a tropical lowland rainforest of central Amazônia, including methodological and conservation considerations. Studies on Neotropical Fauna and Environment 38 (1): 17-31.

Simmons, N.B. \& R.S. Voss. 1998. The mammals of Paracou, French Guiana: A neotropical lowland rainforest fauna. Part 1: bats. Bulletin American Museum Natural History 237: 1-219.

Soberón, J. \& J. Llorente, J. 1993. The use of species accumulation functions for the prediction species richness. Conservation Biology 7: 480-488.

Uieda, W. \& W.A. Pedro. 1996. Chiroptera in the XXI Brazilian Zoology Congress. Chiroptera Neotropical 2 (1): 41-42.

Ururahy, J.C.C.; J.E.R. Collares; M.M. Santos \& R.A.A. Barretos. 1983. As regiões fitoecológicas, sua natureza e seus recursos econômicos. Estudo fitogeográfico. Rio de Janeiro, Projeto RadamBrasil, Folhas 23-24, vol. 4, 780p.

Voss, R.S. \& L.H. Emmons. 1996. Mammalian diversity in neotropical lowland rainforests: a preliminary assessment. Bulletin of the American Museum of Natural History 230: 1-115.

WeLLER, T.J. \& D.C. LEE. 2007. Mist net effort required to inventory a forest bat species assemblage. Journal of Wildlife Management 71 (1): 251-257.

ZAR, J.H. 1996. Biostatistical analysis. New Jersey, PrenticeHall, $3^{\text {rd }}$ ed., 662p.

Submitted: 06.VII.2008; Accepted: 12.III.2009.

Editorial responsibility: Fernando de Camargo Passos 